\title{
YOUTH AND MOBILE ADVERTISEMENTS: AN ANALYSIS OF CONSUMER BUYING BEHAVIOUR IN PAKISTAN
}

\author{
Syed Muhammad Saqib Saleem ${ }^{1 *}$ and Sadia Khalid ${ }^{2}$ \\ ${ }^{1}$ Forman Christian College (A Chartered University) Lahore, Pakistan \\ ${ }^{2}$ University of Management and Technology, Lahore, Pakistan
}

\begin{abstract}
The total number of mobile phone users across the globe has increased from 4 to 4.77 billion in the past 5 years and is expected to cross 5 billion by the end of 2019. Like the rest of the world, Pakistan has seen an increase in cellular subscribers; going from 88 to 139 million in the last 10 years; majority between the age of 21 and 30 years. The focus of this research is to study the impact of mobile phone advertisements on consumers' buying behavior. The increasing competition has lead mobile companies to invest humongous amounts of money into creating beguiling advertisements; from having national and international celebrity endorsements to heart-touching storylines to groovy music beats. A questionnaire was devised to help gather data about the topic under consideration; based on random probability sampling, the youth enrolled in undergraduate programs in private/public sector universities of Lahore, Pakistan was targeted. The AIDA model served as the basis of analyzing the collected stats. The results indicate that despite the lavishly created advertisements, users are more inclined to buy phones of a certain brand. Also, the advertisements are not playing much role in influencing buying behavior of mobile phone consumers and they are, still, more concerned about the features of the phone rather than the attractiveness of the advertising gimmicks.
\end{abstract}

Keywords: mobile phone advertisements, consumer buying behavior, brand identity, advertising gimmicks.

\section{Introduction}

There was a time when humans lived simply, a time before companies started packing every communication channel with advertisements. Advertising, back then, was just a helpful suggestion about something needed. But with time, basic human needs were re-defined and luxuries were turned into basic necessities. Companies started competing for a few seconds of their consumers' attention and time. Suddenly, advertising became pervasive; appearing everywhere around the globe. As explained by David Ogilvy:

"There isn't any significant difference between the various brands of whiskey or cigarettes or beer. They are all about the same. And so are the cake mixes and the detergents and the margarines . . The manufacturer who dedicates his advertising to building the most sharply defined personality for his brand will get the largest share of the market at the highest profit."

Since then, the term "brand" is getting stronger and stronger and the effort to create one is becoming nothing less than a convoluted journey. It is actually the public's attention to one's business that increases the selling rate and it is a joining appeal between consumer and producer. The purpose of advertising is to make costumers aware that a product or service is right for their needs. It creates an urging desire for the products or services. And it enhances the image of the company.

Advertising has grown to become more pertinent to the process of disseminating an idea or information about a product. When government relies increasingly on sophisticated public relation agencies or public debate corners, a sense of public affiliation is created. In the same way, when advertisers rely on advertising, a creative strategy 
of advertising is created between producers and consumers. In order to understand the consumer demands and their inclination towards particular ideas, their behavior must be studied closely; consumer behavior is how an individualmakes his mind to choose or use or discardany product or service offered by another entity, and how his choices impact other consumers and society.

\section{Consumer Decision Making Stages}

A consumer goes through the following stages before purchasing a product:

Need: this acts as the trigger for the whole process

Information Gathering: the information can be gathered from a number of various personal (acquaintances share information with respect to their own experiences with the product) and commercial resources.

Evaluating Alternatives: these evaluations are done on the basis of shared experiences, allocated budget and personal preferences.

Purchasing: if the initial stages are cleared successfully, the product is finally purchased.

Feedback: this stage decides whether the consumer need was fulfilled and whether the product would be chosen or recommended by the consumer in future.

According to a study conducted by Apejoye A. in 2013, celebrity endorsement was a very influential factor when it comes to college students recalling endorsed advertisements and buying products.

The same findings were supported by another research of 2015(Ahmedet al), celebrity endorsement adds a glam factor to a mobile phone brand's identity and helps increase the preference and consumption rate.

\section{Advertising Effect Model - AIDA}

"The aim of marketing is to know and understand the customer so well, the product or service fits him and sells itself" (Peter Drucker). The major aim of advertising is to impact the decision making process of the consumers. With the growing competition, advertisers have started to appeal to the emotional and psychological side of the consumers; like portraying a caring mother, a dying patient or a happy child. A brand is what a consumer can remember about a product.

Traditionally, the advertising effects are studied via a hierarchical model AIDA, consisting of four states:

Attention: advertisers create eye-catching displays and content to attract the consumers.

Interest: this state refers to the interest of the consumer with the advertised content

Desire: if the product is advertised cleverly, the interest levels are raised to an unavoidable need.

Action: the final state leads to purchasing.

\section{Usage of Mobile Phones}

The importance of mobile phones in lives of people today cannot be emphasized enough; it has become the ultimate necessity. According to Bridgeset al (2010), the worldwide penetration rate of mobile phone usage hasincreased from $5 \%$ to $61 \%$ within 10 years. 
A study (Wohlfahrt, 2002)found that the number of mobile phone users from 1997 to 2001 increased from 215 million to 961 million. The study predicted the number to reach 1.16 billion by 2003 . Also, the highest penetration was recorded to be $79 \%$ in Western Europe, $48 \%$ in North America and $12 \%$ in Asia.

According to a survey conducted by Statista in 2015, the total number of mobile phone users across the globe increased from 4 to 4.77 billion in the past 5 years and was expected to cross 5 billion by the end of 2019 .

\section{Situation in Pakistan}

According to the findings of the Pakistan Advertisers' Society, Pakistan has seen an increase in cellular subscribers; going from 88 to 139 million in the last 10 years.

Thus, the worldwide consumer market of mobile phones has grown really strong over the years and with this, the advertisers are continuously improving their standards of mobile phone advertisements. As said by David Ogilvy, "The more informative your advertising, the more persuasive it will be"; the advertisers make their consumers feel an emotional attachment with their product. This sense of affiliation makes the consumer stick to that product.

S. Mokhlis and A. Y. Yaakop (2012) conducted a research on the how consumer choose a buy a certain mobile phone in Malaysia. The findings highlighted price, features and personal recommendations to be the influential aspects while buying.Similarly, Karjaluotoet al(2005) investigated in Finland and found the same things to be the most important considerations while purchasing a new mobile phone.

\section{Youth and Mobile Phones}

Youth is the driving force of a nation and various studies conducted worldwide showed them to be the most targeted sample while studying mobile phones.

The study by M. Hakoama and S. Hakoyama (2011) showed that half of the population of targeted college students was a frequent user of mobile phones and $90 \%$ had been using mobile phones for more than 3 years.

Aoki and Downes (2003) concluded that majority of the college students use mobile phones given by their parents for remaining in touch with family and friends.

A study by Audrey N. Selianin 2004reported over 103 million mobile phone users between the ages of 5 and 24 by January 2002. The study was conducted in the combined markets of a number of countries, including the USA, UK, Australia and Japan. The numbers were expected to rise by $47 \%$ in 2004 to 152 million. Also, 34\% of the USA youth, between 13 and 24 years of age, had mobile phones.

\section{Situation in Pakistan}

A study conducted by the Pakistan Advertisers' Society revealed the youth was the major user of mobile phones in the country. The study showed that of all mobile users, $9 \%$ were of 10 to 20 years old, $77 \%$ below $30,12 \%$ below 40 and only $1 \%$ were above 40 years of age.

A study conducted by PEW Research Center compared the stats of mobile users around the globe with Pakistan and found that majority of countries have age group between 18 and 29 as the major mobile users. 


\section{Research Methodology}

\section{Hypothesis}

As per the findings, the hypotheses formed for this study are:

H1 - consumer buying behavior is affected by celebrity endorsements

$\mathrm{H} 2$ - consumer buying behavior, in case of mobile phones, is affected majorly by price and features.

\section{Setup}

The sample selected for this research is based on probability random sampling method; where the youth is getting targeted, as per the findings about age groups. The sample consisted of people between the ages 18 and 25, selected randomly from 4 different universities of Lahore, Pakistan. Cluster identification was used on the selected sample and 25 boys and girls each were selected; 50 students from each university.

A questionnaire, comprising of 16 questions was devised for the study. The questionnaire focuses on various aspects of mobile phone advertisements and their impact on the viewers in terms of buying decisions.

\section{Findings and Analysis}

The study revealed that iPhone and Samsung were the most commonly used brands among students (as shown in Figure 1) and $98 \%$ of the respondents were affiliated with the brand they were using. In Pakistan, iPhone has no official advertisements, apart from the ones shared on social media. So, the results indicate that buying behavior is influenced by brand identity, with or without the presence of advertisements. Advertisements do help in making a brand identity stronger but in case where the advertisements are absent, there are other things to help strengthen that identity; as proved by this study.

In the case where brand advertisements are present, people do watch them; as proved by this study in Figure 2. These advertisements provide the viewers with information about a certain brand and people do grasp that information (shown by Figure 3). This information can be about something new about a product or brand or it can just be strengthening a factor already associated with the product or brand (shown by Figure 4). Either way, the information shared by the advertisers reach the viewers.

However, the consumer buying behavior is dependent on what exactly is being portrayed in the advertisements. An advertisement portrays a lot of different aspects; starting from the features of a mobile phone, to celebrities endorsing it, to real life stories or fiction revolving around a mobile phone. A few of these aspects were explicitly mentioned in the questionnaire and the students were asked to pick the most suitable ones. As shown by Figure 5, the information reaching the viewers is majorly about celebrities endorsing a mobile phone. Figure 6 , on the other hand, tells about what a mobile phone advertisement viewer gets attracted by in the advertisements. As per the findings, the brand name is the biggest attraction, followed by celebrities endorsing it.

So, analyzing these two figures, it can be said that majority of the advertisers are focusing on the areas which are not needed by the viewers to feel attracted towards their product or brand.

Exploring the buying behavior, the students were asked if they watch advertisements before making a purchase and the results were majorly between agree and neutral, as shown in Figure 7. The influence of these advertisements on their buying choices is shown in Figure 8 and it indicates that advertisements often influence the buying choices of the consumers. 
Based on the conclusion of Figure 5 and Figure 6, the advertisements were not showing what the consumers wanted to see, yet they were affecting the buying choices, as per the conclusion of Figure 7 and Figure 8.

In order to explore the impact of each major aspect of advertisement, a few questions were directed towards the students. Figure 9 and Figure 10 shows that advertisements sometimes can get viewers emotionally connected to a certain brand. But majorly, the advertisements play no role in making emotionalattachments between viewers and the brand.

Similarly, the celebrities endorsing brands, entertaining advertisementsand attractive music fails to affect the consumer buying behavior; as shown in Figure 11.

In order to find out the exact mental condition of consumers while purchasing a mobile phone, a question about their preference was asked and the findings proved that features of a mobile phone is the only thing on a consumers mind while going for the purchase, as shown in Figure 12.

So, the answers indicated that if a brand identity is strong, advertisements are not needed. Also, the advertisers creating advertisements for mobile phones are focusing on so much various elements that they are ignoring the basic things which can influence consumer buying behavior. The amount of money being spend on the hi-tech advertisements, creative storytelling and engaging celebrities is adding to the glam but is not paying back like it should.

So, if a consumer's buying behavior is getting influenced by an advertisement which is not focusing on the features of a mobile phone, then perhaps, the influence is negative to the product or brand i.e. a consumer feels that if a brand is not intelligent enough to create a meaningful advertisement; showcasing the features of a mobile phone; then perhaps the phone has nothing much to offer.

\section{Conclusion}

The objective of the research was to investigate the impact of advertisement about mobile phones on youths' buying behavior in Pakistan. As per the findings of this study, mobile phone advertisements do provide information to the viewers but they lack meaningful content. As a result, the impact of these advertisements is rarely positive for the product or brand. The companies in Pakistan are spending massive amounts of money in creating quality advertisements but the users are concerned with the features offered by the product; which are hardly a part of these advertisements. Thus, they enjoy the advertisements but they do not feel connected to the brand or product.

The study also found that most of the consumers are brand loyal; which means that they will stick to one particular brand without any help from advertisements. With the growing market competition, a lot of things need to be considered to have a successful brand identity and meaningful advertisement is one such thing.

\section{References}

4 Timeless Marketing Lessons from Don Draper and David Ogilvy, Date of access: 21/10/2017. https://www.randallreilly.com/4-timeless-lessons-from-don-draper-and-david-ogilvy/

Consumer Behavior: The Psychology Of Marketing, Date of access: 21/10/2017. http://www.consumerpsychologist.com/index.html

Stages in Consumer Decision Making Process, Date of access: 21/10/2017. http://www.managementstudyguide.com/consumer-decision-making-process.htm

Mobile Phone Users in Pakistan Cross 139.2 Million Mark, Date of access: 25/10/2017. http://www.pas.org.pk/mobile-phone-users-in-pakistan-cross-139-2-million-mark/

Smart Phone Usage in Pakistan, Date of access: 25/10/2017.

http://www.pas.org.pk/smart-phone-usage-in-pakistan-infographics/ 
Number of mobile phone users worldwide from 2013 to 2019 (in billions), Date of access: 29/11/2017

https://www.statista.com/statistics/274774/forecast-of-mobile-phone-users-worldwide/

Mobile Phones and Youth: A Look at the US Student Market, Date of access: 27/10/2017. https://www.itu.int/osg/spu/ni/futuremobile/Youth.pdf

David Ogilvy on Advertising: his 7 commandments and quotes all Marketers must know, Date of access: 25/10/2017.

https://postcron.com/en/blog/david-ogilvy-7-commandments-advertising-marketers-need-know/

32 Great Quotes From Advertising \& Marketing Experts, Date of access: 25/10/2017. https://www.ventureharbour.com/great-quotes-advertising-marketing-experts/

DAWN, 2010, The rise of mobile and social media use in Pakistan. Daily Dawn, 29 April.

Audrey N. Selian, 2004, Mobile Phones and Youth: A Look at the US Student Market, Paper presented at the ITU/MIC Workshop on Shaping the Future of Mobile Information Society, Seoul, Korea

Aoki, Kumiko and J. Downes, Edward, 2003, An analysis of Young People's Use of and Attitudes Toward Cell Phones, Telematics and Informatics, 20, 349-364, 10.1016/S0736-5853(03)00018-2.

S Mokhlis, AY Yaakop, Consumer Choice Criteria in Mobile Phone Selection: An Investigation of Malaysian University Students, International Review of Social Sciences and Humanities, 2 (2), 203-212.

Karjaluoto, Heikki and Karvonen, Jari and Kesti, Manne and Koivumäki, Timo and Manninen, Marjukka and Pakola, Jukka and Ristola, Annu and Salo, Jari, 2005, Factors Affecting Consumer Choice of Mobile Phones: Two Studies from Finland, Journal of Euromarketing, 14, 10.1300/J037v14n03_04.

Hakoama, M \& Hakoyama, S., 2011, The impact of cell phone use on social networking and development among college students, The American Association of Behavioral and Social Sciences Journal, 15. 1-20.

Adebija A., 2010, As Celebrity winds of endorsement sweep the land. Daily Independent 29 October.

Apejoye A., 2013, Influence of Celebrity Endorsement of Advertisement on Students' Purchase Intention. Journal of Mass Communication \& Journalism 3, 1-7.

Ahmed, Rizwan \& Kumar Seedani, Sumeet \& Kumar Ahuja, Manoj and Kumar Paryani, Sagar, (2015), Impact of Celebrity Endorsement on Consumer Buying Behavior, SSRN Electronic Journal, 10.2139/ssrn.2666148.

Laurie Bridges, Hannah Gascho Rempel, Kimberly Griggs, 2010, Making the case for a fully mobile library web site: from floor maps to the catalog, Reference Services Review, Vol. 38 Issue: 2, pp.309-320.

Dr. Mohammad R. S., Sara T., Nasim M. S., 2014. Investigating the Types of E-Advertising Strategy and its Influence on Consumer Buying Behavior. European Journal of Business and Management, 6(7), 262-266.

Wohlfahrt, J., "Wireless Advertising", Mobile Commerce: Grundlagen, Geschäftsmodelle, Erfolgsfaktoren, Günther Silberer, Jens Wohlfahrt and Thorsten Wilhelm (eds.), Gabler, Wiesbaden, pp. 245-263, 2002.

\section{Appendix}




\section{WHICH MOBILE PHONE BRAND ARE YOU} USING?

Eamsung Iphone $\square$ Qmobile Nokia $\quad$ Anyother

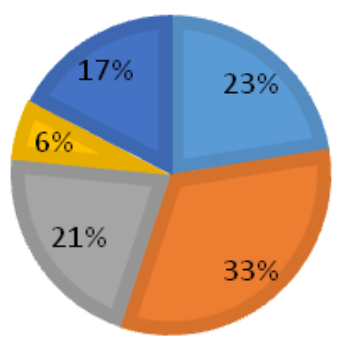

Figure 1:Commonly used mobile phone brands

\section{DO YOU WATCH ADVERTISEMENTS ABOUT MOBILE PHONES?}

$$
\text { negularly } \quad \text { Often } \quad \text { Rarely } \quad \text { Never }
$$

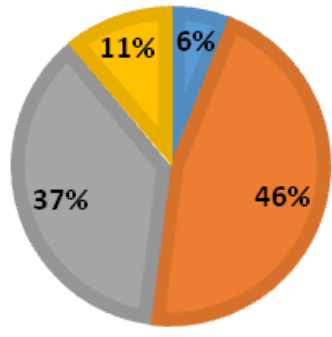

Figure 2:View rates of mobile phone advertisements

\section{DO YOU THINK THESE ADVERTISEMENTS \\ ARE A SOURCE OF SPREADING AWARENESS ABOUT A CERTAIN BRAND?}

- Strongly agree $\quad$ Agree $\quad$ Neutral Disagree $\quad$ Strongly Disagree

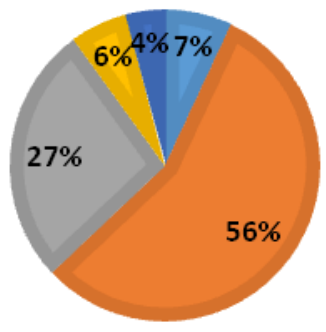

Figure 3 Rate of brand awareness advertisements 


\section{DO THESE ADVERTISEMENTS GIVE YOU ANY NEW INFORMATION ABOUT A CERTAIN BRAND?}

$\square$ Yes No

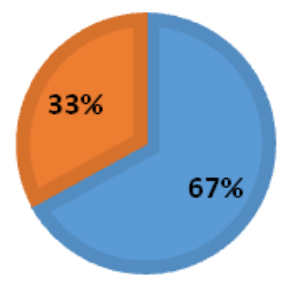

Figure 4 Rate of new information providing advertisements

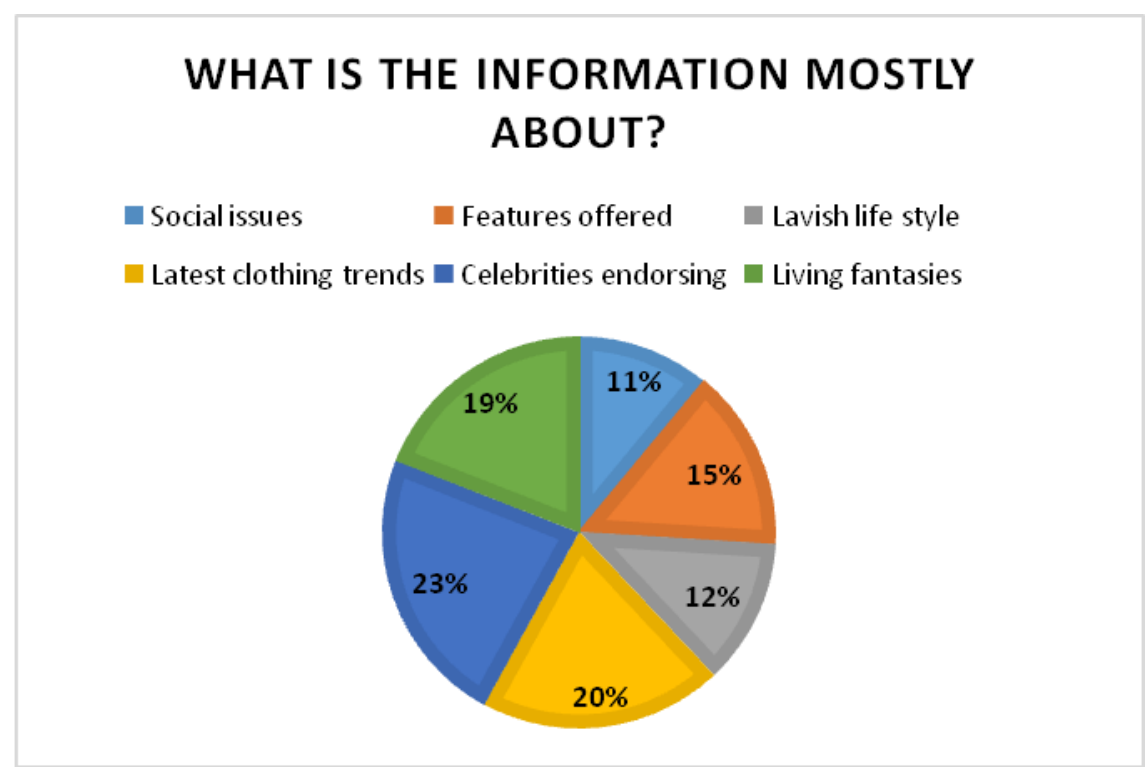

Figure 5 Rate of various kinds of information provided by advertisements

\section{WHAT ATTRACTS YOU IN A MOBILE PHONE ADVERTISEMENT?}

Brand name

n Celebrity endorsement $\square$ Humor

Good graphics

a Jingle

- Social awareness

- Real life portrayal

- Emotional stories

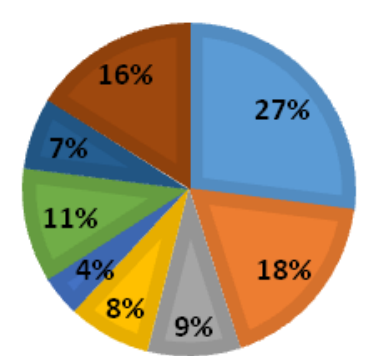


Figure 6 Rate of various attraction sources in advertisements

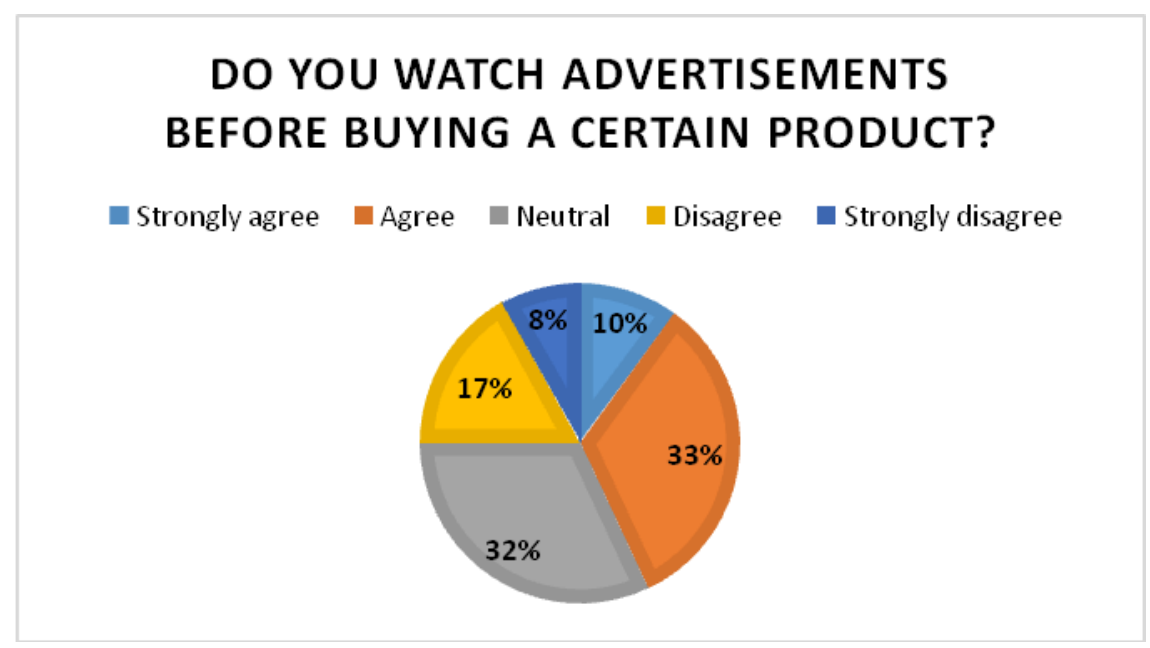

Figure 7Importance of advertisements in buying decisions

\section{DO THESE ADVERTISEMENTS MAKE YOU CHANGE YOUR DECISION ABOUT BUYING A CERTAIN BRAND?}

always $\square$ Often $\square$ Rare $n$ Never

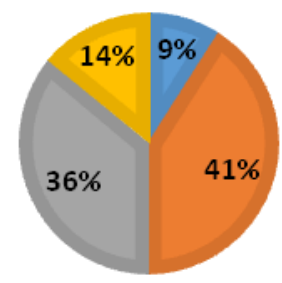

Figure 8 Impact of advertisements on buying behavior

\section{DO THESE ADVERTISEMENTS MAKE YOU EMOTIONALLY ATTACHED WITH A CERTAIN BRAND?}

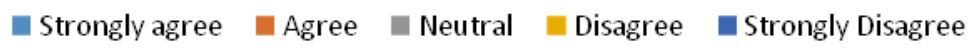

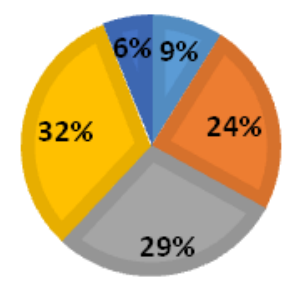

Figure 9Emotional influence of advertisements 
IF YOU CAN PERSONALLY RELATE TO A MOBILE PHONE ADVERTISEMENT, DOES IT INCREASE YOUR CHANCES OF BUYING THAT PHONE?

$$
\square \text { Yes No }
$$

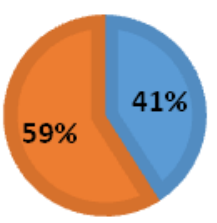

Figure 10 Impact of emotional attachment to an advertisement

\section{DOES THE FOLLOWING PERSUADE YOU TO BUY A MOBILE PHONE?}

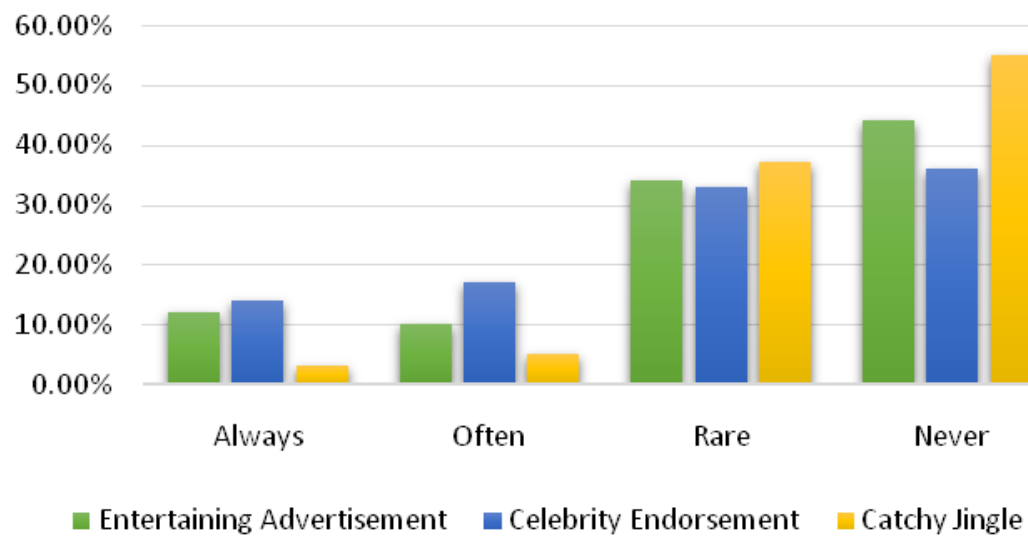

Always

Often

Rare

Never

Entertaining Advertisement $\quad$ Celebrity Endorsement $\quad$ Catchy Jingle

Figure 11Impact of various elements portrayed in an advertisement on buying behavior

\section{WHILE BUYING A NEW MOBILE} PHONE, WHAT DO YOU LOOK FOR?

- Features and specifications $=$ Celebrity endorsement

- Entertaining advertisement

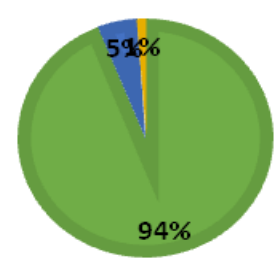

Figure 12 Mobile phone consumer preferences 


\section{Questionnaire}

1.Which cell phone brand are you using?

- Samsung

- I phone

- Q mobile

- Nokia

- Any other

2.Are you affiliated with this specific brand?

- Yes

- No

3.Do you watch advertisements about cell phones?

- Regularly

- Often

- Rarely

- Never

4.Do you think these advertisements are a source of spreading awareness about a certain brand?

- Strongly agree

- Agree

- Neutral

- Disagree

- Strongly Disagree

5.What attracts you in a cell phone advertisement?

- Brand name

- Celebrity endorsement

- Humor

- Good graphics

- Jingle

- Social awareness

- Real life portrayal

- Emotional stories

6.How often do you change your cell phone?

- Monthly

- Quarterly

- Yearly

- More than that

7. While buying a new cell phone, what do you look for?

- Celebrity endorsement

- Entertaining advertisement

- Features and specifications

8.Do you watch advertisements before buying a certain product?

- Strongly agree

- Agree 
Syed Muhammad Saqib Saleem and Sadia Khalid / Youth And Mobile Advertisements..

- Neutral

- Disagree

- Strongly disagree

9.Do these advertisements make you emotionally attached with a certain brand?

- Strongly agree

- Agree

- Neutral

- Disagree

- Strongly Disagree

10.Do these advertisements give you any new information about a certain brand?

- Yes

- No

11.If yes, what is the information mostly about?

- Social issues

- Features offered

- Lavish life style

- Latest clothing trends

- Celebrities endorsing

- Living fantasies

12.Do these advertisements make you change your decision about buying a certain brand?

- Always

- Often

- Rare

- Never

13.Does an entertaining advertisement persuade you to buy a certain cell phone?

- Always

- Often

- Rare

- Never

14.Does a celebrity endorsement persuade you to buy a certain cell phone?

- Always

- Often

- Rare

- Never

15.Does a catchy jingle persuade you to buy a certain cell phone?

- Always

- Often

- Rare

- Never

16. If you can personally relate to a cell phone advertisement, does it increase your chances of buying that phone?

- Yes

- No 